\title{
Anti-wrinkle efficacy of isoquercitrin isolated from Nymphoides indica
}

\author{
Jae-Myo Yu ${ }^{1}$ (i) $\cdot$ Yun-Hwan Kang ${ }^{1} \cdot$ Dong-Hee Kim $^{1} \cdot$ You-Ah Kim ${ }^{2} \cdot$ \\ A-Hyun Kim ${ }^{2} \cdot$ Byoung-Jun Park ${ }^{2} \cdot$ Tae-Soon Park ${ }^{1}$

\section{어리연꽃에서 분리된 Isoquercitrin의 주름개선 효능 연구}

\author{
유재묘 ${ }^{1}$ - 강윤환 ${ }^{1}$ 김동희 ${ }^{1} \cdot$ 김유아 $^{2}$ - 김아현 ${ }^{2} \cdot$ 박병준 $^{2} \cdot$ 박태순 $^{1}$
}

\begin{abstract}
In this study, we evaluated the possibility of wrinkle-reducing functional cosmetic material of isoquercitrin (IQC) isolated from Nymphoides indica (NP) by measuring the efficacy of ROS inhibition, procollagen synthesis induction, and matrix metalloproteinase (MMP)-1 inhibition. As a result, ROS tended to be inhibited in a concentration dependent manner, and the procollagen protein synthesis rate was increased by $70 \%(5 \mu \mathrm{g} / \mathrm{mL})$ and the MMP-1 protein was decreased by $41 \%(5 \mu \mathrm{g} / \mathrm{mL})$ compared with the control. This was suggested the ability of IQC to induce the procollagen synthesis and to reduce the ROS and MMP-1 production. Therefore, it is considered that IQC isolated from NP has enough value to be a functional cosmetic material.
\end{abstract}

Keywords Anti-oxidant $\cdot$ Anti-wrinkle $\cdot$ CCD-986sk $\cdot$ Elastase $\cdot$ Nymphoides indica $\cdot$ Procollagen

\section{서 론}

피부 노화는 자외선(UV)에 의해서 많은 영향을 받는데 이로 인 한 노화를 광노화(photoaging)라고 하며 외인성 노화 중 하나로 알려져 있다[1].

Tae-Soon Park $(\square)$

E-mail: taesoon2p@nikom.or.kr

${ }^{1}$ Department of Korean Medicine Development, National Development Institute of Korean Medicine, 94, Hwarang-ro, Gyeongsan-si, Gyeongsangbukdo, 38540, Republic of Korea

${ }^{2}$ Skin Science Research Institute, Kolmar Korea Co., Ltd., 76, Yeongudanjiro, Ochang-eup, Cheongwon-gu, Cheongju-si, Chungcheongbuk-do 28116 , Republic of Korea

This is an Open Access article distributed under the terms of the Creative Commons Attribution Non-Commercial License (http://creativecommons. org/licenses/by-nc/3.0/) which permits unrestricted non-commercial use, distribution, and reproduction in any medium, provided the original work is properly cited.
UV에 의해 reactive oxygen species (ROS)가 생성되면 matrix metalloproteinase (MMP)와 collagen 분해를 유도하고 procollagen 의 합성 감소를 일으켜 주름을 유발한다[2]. 또한, UV에 의한 MMPs 활성화와 그로 인한 주름 유발은 activating protein-1에 의한 것으로 알려져 있다[3,4]. MMPs는 collagenase, stromelysin, gelatinase, membrane-type MMP 등으로 나눌수 있고, 다양한 종류가 보고되어 있다[5]. 그 중 MMP-1은 collagenase로서 collagen type I, II 그리고 III을 분해하기 때문에 이를 억제시 키는 것은 중요하다[6,7]. 따라서 ROS를 제거하거나 collagenase 의 작용을 억제하고 collagen의 합성을 촉진하는 소재의 발굴은 중요하다. 기존에 사용되고 있는 비타민 $\mathrm{A}$, 비타민 $\mathrm{C}$ 등 다양 한 항산화제가 있지만 피부 안전성의 문제로 부작용이 적은 천 연물을 이용한 소재를 개발하고자 한다[8].

본 연구에서는 다년생, 부엽성 수생식물로서 조름나물과 (Menyanthaceae)에 속하는 어리연 꽃(Nymphoides indica (L.) Kuntze)을 이용하여 연구하였다. 주로 정원에 식재되거나 습지 에 분포하는 대표적인 수생식물로서[9] 잎은 마주나며 물위에 뜨고, 꽃은 6-9월에 황색으로 잎겨드랑이(葉緣)에서 하나씩 핀 다. 예로부터 민간요법으로 뱀독, 해열, 항경련 등의 치료에 사 용되었고 우리나라에는 어리연꽃, 노랑어리연꽃, 좀어리연꽃 3 종이 자생한다[10]. 기존에 보고된 연구로는 '노랑어리연꽃 잎 에서 분리된 성분의 약리학적 효과[11]'가 보고되어 있지만 항 노화 효능에 대한 연구는 미미하다.

따라서 어리연꽃의 분획물에서 분리된 성분으로 항노화관련 활 성을 평가하여 천연유래의 항노화 소재로서 가치를 검증하고자 한다.

\section{재료 및 방법}

추출 및 분리

본 연구에서 사용한 시료인 어리연꽃은 농업회사법인 (주)로터 
스그린에서 구입하여 사용하였다. 또한, 이 시료는 생물 종 판 별 시스템에 의해 확증표본(NIBRVP000012545)으로 확인되었 으며, 확인은 국립생물자원관 생물자원연구부 식물자원과를 통 해 진행되었다. 추출은 건조된 시료를 $100 \%$ methyl alcohol에 침지시켜 72 시간 동안 두었으며 이 과정을 3 회 반복하여 농축 및 동결건조하여 추출물을 확보하였다. 추출물을 용매의 극성에 따라 순차적으로 분획하였으며, ethyl acetate 분획물을 medium pressure liquid chromatography (Isocratic, Water: $\mathrm{ACN}=80: 20$, $\mathrm{v} / \mathrm{v}, 40 \mathrm{~min})$ 을 수행하여 화합물 $(55.3 \mathrm{mg})$ 을 분리하였다.

\section{시료 및 기기}

유효성분의 분리 및 정제는 preparative-liquid chromatography (LC-Forte/R, YMC, Kyoto, KP, Japan)로 하였고, 화합물의 구 조 동정은 Bruker Ascend 400 (Bruker, Karlsruhe, BW, Germany)을 사용하여 NMR 측정을 실시하였다. 효능 측정을 위한 elastase의 경우 porcine pancreas elastase를 사용하였으며, n-succinyl-(L-Ala) $)_{3}$-p-nitroanilide와 함께 Sigma chemical Co. (St. Louis, MO, USA)에서 구입하여 사용하였다. 세포 배양 배 지와 시료인 dulbecco's modified eagle medium (DMEM), fetal bovine serum, penicillin/streptomycin 은 gibco BRL Co. (Grand Island, NY, USA)에서, 세포독성 측정 시약 3-[4,5dimethylthiazol-2-yl]-2,5-diphenyl-tetrazolium bromide (MTT)은 Sigma-Aldrich (St Louis, MO, USA)에서 구입하였다. 항노화 활성 측정은 $\mathrm{ROS}-\mathrm{Glo}^{\mathrm{TM}} \mathrm{H}_{2} \mathrm{O}_{2}$ assay kit (Promega, Madison, WI, USA), MMP-1 ELISA kit (Abcam, Cambridge, MA, USA), procollagen type I C-peptide kit (Takara Shuzo, Kyoto, $\mathrm{KP}$, Japan)와 pro-COL1A1, MMP-1, $\beta$-actin 항체(Santa Cruz Biotechnology, Santa Cruz, CA, USA)를 각각 구입하여 사용 하였다.

\section{Elastase 저해활성 측정}

Isoquercitrin (IQC)을 $5,10,50,100 \mu \mathrm{g} / \mathrm{mL}$ 로 희석하여 $40 \mu \mathrm{L}$ 씩 96 well plate에 넣은 뒤 $2.5 \mathrm{U} / \mathrm{mL}$ porcine pancreas elastase 와 n-succinyl-(L-Ala) $)_{3}$-pnitroanilide $(0.5 \mathrm{mg} / \mathrm{mL})$ 를 $50 \mathrm{mM}$ tris$\mathrm{HCl}$ buffer $(\mathrm{pH}$ 8.6)에 녹여서 well에 넣고 $30 \mathrm{~min}$ 반응 후 $445 \mathrm{~nm}$ 에서 측정하였다[12]. 시료용액의 첨가구와 무첨가구의 흡광도 감소율 $(\%)$ 로 elastase 저해활성을 나타내었다.

\section{MTT assay에 의한 세포 독성 측정}

본 실험에 사용된 IQC의 세포독성을 확인하기 위해 CCD-986sk cell을 48 well plate에 각각 $5 \times 10^{3}$ cells/well로 분주하고 24 시 간 안정화하였다. 그 후 $\mathrm{IQC}$ 를 $0.5,1,5,10,20 \mu \mathrm{g} / \mathrm{mL}$ 로 희 석하여 처리한 후 48 시간 동안 $37^{\circ} \mathrm{C}, 5 \% \mathrm{CO}_{2}$ incubator에서 배양하였다. 48 시간 후 $5 \mathrm{mg} / \mathrm{mL}$ 농도의 시약을 4 시간 반응시 키고 demethyl sulfoxide $500 \mu \mathrm{L}$ 를 넣어서 녹여주었다. 그 후 microplate reader를 이용하여 $540 \mathrm{~nm}$ 에서 흡광도를 측정하였다.

\section{$\mathrm{ROS}$ 생성량 측정}

ROS 생성량을 측정하기 위해 CCD-986sk cell을 48 well plate 에 각각 $5 \times 10^{3}$ cells/well로 분주하고 24 시간 안정화하였다. 이 후, 배지를 제거하고 $\mathrm{PBS}$ 를 넣어 UVB $\left(20 \mathrm{~mJ} / \mathrm{cm}^{2}\right)$ 를 처리하 였다. 다시 $\mathrm{DMEM}$ 배지를 넣고 $\mathrm{IQC}$ 를 $0.5,1,5 \mu \mathrm{g} / \mathrm{mL}$ 농도
로 처리하여 48시간 배양 후, ROS 발생양을 ROS-Glo ${ }^{\mathrm{TM}} \mathrm{H}_{2} \mathrm{O}_{2}$ assay kit를 사용하여 측정하였다.

\section{Procollagen 및 MMP-1 분비량 측정}

Procollagen과 MMP- 1 의 발현양은 procollagen type I Cpeptide kit와 MMP-1 ELISA kit를 사용하여 측정하였다. CCD-986sk cell을 48 well plate에 각각 $5 \times 10^{3}$ cells/well로 분 주한 후 24시간 배양하고 UVB $\left(20 \mathrm{~mJ} / \mathrm{cm}^{2}\right)$ 를 조사한 뒤 $\mathrm{DMEM}$ 배지로 교환하여 시료를 48시간 처리하였다. 그 후 상 등액을 취해 각각의 kit로 측정하였다.

\section{세포내 Procollagen 및 MMP-1 단백질 발현량 측정}

CCD-986sk cell을 6 well plate에 $1 \times 10^{5}$ cells/well로 분주하여 24 시간 배양하고 UVB $\left(20 \mathrm{~mJ} / \mathrm{cm}^{2}\right)$ 를 처리하였다. 그 후 IQC 를 $0.5,1,5 \mu \mathrm{g} / \mathrm{mL}$ 농도로 처리하고 48 시간 배양하였다. 준비 된 cell을 RIPA buffer (Pierce, Appleton, WI, USA)로 단백질 추출한 후 $\mathrm{BCA}$ protein assay (Pierce)을 이용해 정량하였다. 동량의 단백질 sample들을 $10 \% \mathrm{SDS}-\mathrm{PAGE}$ 로 전기영동하고 PVDF membrane으로 transfer시켜 1, 2차 항체 반응을 했고, 결과는 ImageQuant LAS-4000 (GE life sciences, Taipei, Taiwan)를 사용하여 분석하였다.

\section{통계처리}

본 실험은 SPSS 10.0으로 분산분석(ANOVA: analysis of variance)을 실시하였으며,유의수준 $p<0.05$ 에서 유의차 검정을 하였다.

\section{결과 및 고찰}

\section{화합물 구조결정}

구조 동정을 위해 ${ }^{1} \mathrm{H},{ }^{13} \mathrm{C} \mathrm{NMR}$ 및 $2 \mathrm{D} \mathrm{NMR}$ (HMQC, $\mathrm{HMBC}, \mathrm{COSY})(400 \mathrm{MHz}$ 및 $500 \mathrm{MHz})$ 을 측정하였으며, 분광 학적 데이터와 문헌[13]을 비교하여 화합물을 IQC으로 확인하 였다(Fig. 1).

화합물(IQC)- ${ }^{1} \mathrm{H}-\mathrm{NMR}\left(\mathrm{CD}_{3} \mathrm{OD}, 400 \mathrm{MHz}\right): \delta 12.36(1 \mathrm{H}$, $s$, OH-5), $7.71\left(1 \mathrm{H}, s, \mathrm{H}-2^{\prime}\right), 7.59(1 \mathrm{H}, d d, J=2.0,8.6 \mathrm{~Hz}$, H-6'), $6.86\left(1 \mathrm{H}, d, J=8.6 \mathrm{~Hz}, \mathrm{H}-5^{\prime}\right), 6.38(1 \mathrm{H}, d, J=2.0 \mathrm{~Hz}$, $\mathrm{H}-8), 6.20(1 \mathrm{H}, d, J=2.0 \mathrm{~Hz}, \mathrm{H}-6), 5.25(1 \mathrm{H}, d, J=7.6 \mathrm{~Hz}$, $\mathrm{H} 1 "), \quad 3.73-3.21\left(6 \mathrm{H}, m\right.$, protons of sugar party); ${ }^{13} \mathrm{C}-\mathrm{NMR}$ (CD $\mathrm{OD}, 100 \mathrm{MHz}): \delta 179.6$ (C-4), 166.1 (C-7), 163.2 (C-5), 159.1 (C-9), 158.6 (C-2), $150.0 \quad$ (C-4'), 146.0 (C-3'), 135.8 (C-3), 123.3 (C-1'), 123.2 (C-6'), 117.7 (C-5'), 116.1 (C-2'), 105.8 (C-10), 104.4 (C-1"), 100.0 (C-6), 94.8 (C-8), 78.5 (C5"), 78.2 (C-3"), 75.9 (C-2"), 71.3 (C-4"), 62.7 (C-6").

\section{Elastase 저해활성 측정 결과}

어리연꽃 정제물인 $\mathrm{IQC}$ 의 elastase 활성 억제 효능을 평가한 결과 $5,10,50,100 \mu \mathrm{g} / \mathrm{mL}$ 의 농도에서 각각 $2.7,11.9,22.3,38.3 \%$ 의 억제 활성을 나타내었으며, 이는 대조군인 epigallocatechin gallate (EGCG)보다는 낮지만 비교적 우수한 억제 활성으로 확인되었 다(Fig. 2). 
<smiles>O=c1c(O[C@@H]2O[C@H](CO)[C@@H](O)[C@H](O)[C@H]2O)c(-c2ccc(O)c(O)c2)oc2cc(O)cc(O)c12</smiles>

Fig. 1 Chemical structure of IQC

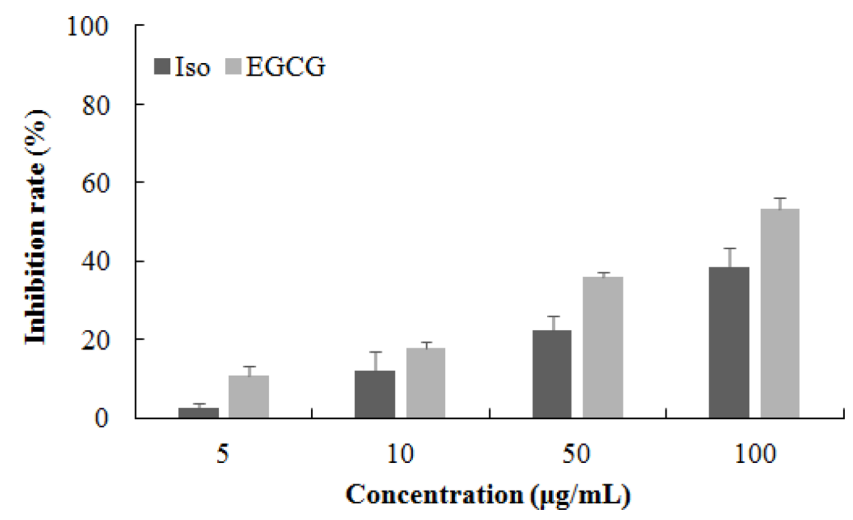

Fig. 2 Elastase inhibition effect of IQC

\section{MTT assay에 의한 세포 독성 측정 결과}

본 실험에 사용된 $\mathrm{IQC}$ 의 세포독성 및 실험 농도를 설정하기 위 해 MTT assay를 수행하였다. CCD-986sk cell에서 독성 측정을 위해 $0.5,1,5,10,20 \mu \mathrm{g} / \mathrm{mL}$ 의 농도로 처리를 하였고 측정 결과는 Fig. 3과 같다. 세포 생존율은 위의 농도에서 각각 99 , $95,93,85,73 \%$ 의 생존율을 보여주었고 이것을 바탕으로 실험 농도는 $0.5,1,5 \mu \mathrm{g} / \mathrm{mL}$ 로 설정하였다.

\section{$\operatorname{ROS}$ 생성량 측정 결과}

ROS는 피부내에서 주름과 관련된 전사인자들을 활성화 시킨다. 이러한 이유로 ROS를 억제하는 것은 피부노화를 방어하기 위 한 주요 방법 중 하나이다. 따라서 $\mathrm{IQC}$ 의 $\mathrm{UVB}$ 조사에 따른 $\mathrm{ROS}$ 의 생성량을 측정하였으며 결과는 Fig. 4와 같다. UVB를 처리한 대조군(Cont)은 비처리군(Nor)보다 ROS의 생성양이 증 가하였으며, $\mathrm{IQC}$ 를 $0.5,1,5 \mu \mathrm{g} / \mathrm{mL}$ 농도로 처리한 경우 농도 의존적으로 $\mathrm{ROS}$ 생성양이 감소되는 것을 확인할 수 있었다.

\section{Procollagen 및 MMP-1 분비량 측정 결과}

$\mathrm{UVB}$ 에 의한 피부 노화는 procollagen의 생성감소와 collagen 양 감소를 유발하는데, 이에 CCD-986sk cell에서 IQC 처리에 의한 propeptide와 $\mathrm{MMP}-1$ 의 분비량을 측정하였다. 측정은 procollagen type I C-peptide kit와 MMP-1 ELISA kit를 사용 하였으며 procollagen은 $0.5,1,5 \mu \mathrm{g} / \mathrm{mL}$ 농도에서 처리군과 비

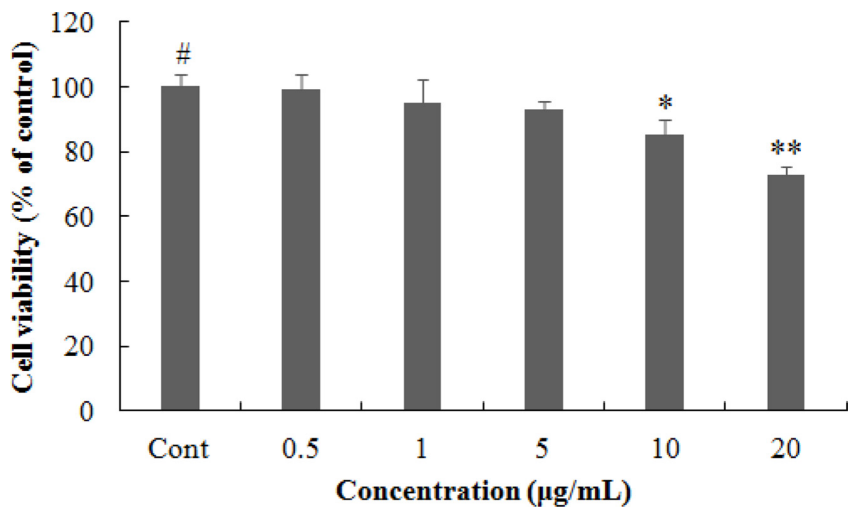

Fig. 3 Dose-dependent cell viability of CCD-986sk by IQC from Nymphoides indica. Cont, treated with UV-B+TNF- $\alpha$. Result are means $\pm \mathrm{SD}$ of triplicate data. ${ }^{\#} p<0.05$ vs. Nor. ${ }^{*} p<0.05,{ }^{*} p<0.01$ vs. Cont.

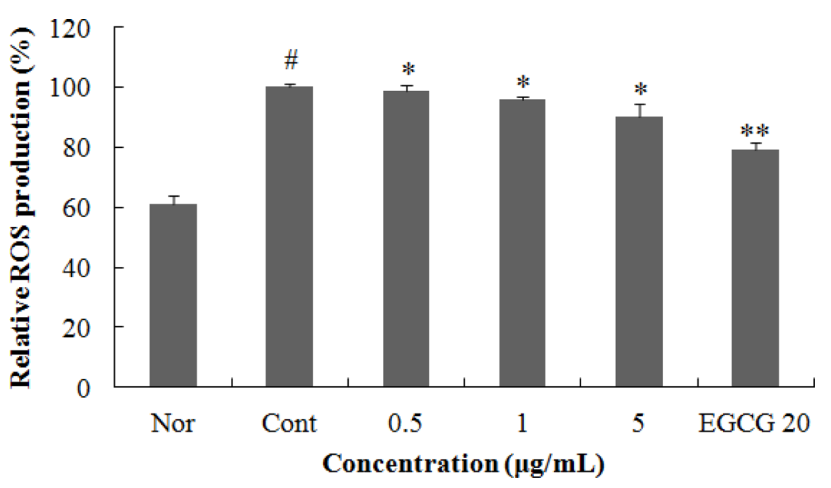

Fig. 4 Inhibition effect of IQC on UVB-induced ROS production in CCD-986sk. Nor, non-treated; Cont, treated with UV-B+TNF- $\alpha$. Result are means $\pm \mathrm{SD}$ of triplicate data. ${ }^{*} p<0.05$ vs. Nor. ${ }^{*} p<0.05,{ }^{* *} p<0.01$ vs. Cont.

교하였을 때 $1,3,10 \%$ 의 생성율 증가를 보여주었고, MMP-1 은 동일 농도에서 $7,12,27 \%$ 의 감소효과를 나타내었다(Fig. 5). 반면 기존에 보고된 연교추출물은 procollagen 합성율이 10 $\mu \mathrm{g} / \mathrm{mL}$ 에서 약 $3 \%, \mathrm{MMP}-1$ 은 $10 \mu \mathrm{g} / \mathrm{mL}$ 에서 $32.7 \%$ 의 억제활 성을 보여[14] 상대적으로 낮은 농도에서 높거나 비슷한 활성 을 보인 IQC가 우수함을 확인하였다.

\section{세포내 Procollagen 및 MMP-1 단백질 발현량 측정 결과}

피부 노화의 특성은 탄력 감소, 주름, 기미 등을 들 수 있고, 그 원인은 탄력섬유인 collagen과 elastin, hyaluronic acid의 사 슬 절단 및 비정상적인 교차결합이다. 따라서 피부 구성 물질 인 collagen, elastin 등의 분해를 유발하는 MMPs의 생합성을 억제하는 것은 중요하다. 이에 procollagen 및 MMP-1의 세포 내 protein 발현을 확인하였고 결과는 Fig. 6과 같다. Procollagen 의 protein 합성율은 $0.5,1,5 \mu \mathrm{g} / \mathrm{mL}$ 농도에서 처리군과 비교 하였을 때 $59,62,70 \%$ 의 높은 합성율 증가를 나타내었으며 EGCG $(20 \mu \mathrm{g} / \mathrm{mL})$ 는 $82 \%$ 로 나타났다. MMP-1 protein의 발현 율은 처리군과 비교하여 $0.5,1,5 \mu \mathrm{g} / \mathrm{mL}$ 순으로 각각 17,25 , $41 \%$ 억제하였고 positive control인 EGCG $(20 \mu \mathrm{g} / \mathrm{mL})$ 와 비슷 한 활성을 보여주었다. 반면 블랙초크베리 분획물은 MMP-1의 protein 발현이 $10 \mu \mathrm{g} / \mathrm{mL}$ 에서 $30 \%$ 정도로 나타났고, procollagen 

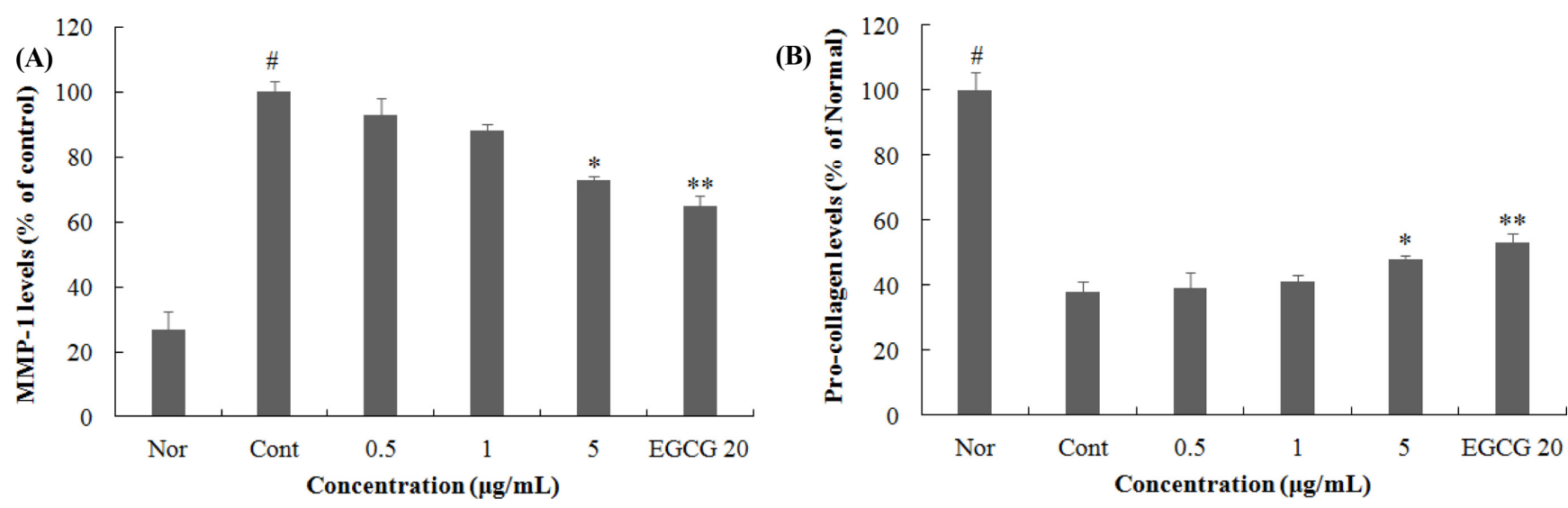

Fig. 5 Recovery effect of IQC on UVB-induced MMP-1 increase (A) and procollagen decrease (B) in CCD-986sk culture media. Nor, non-treated; Cont, treated with UV-B+TNF- $\alpha$. Result are means \pm SD of triplicate data. ${ }^{\sharp} p<0.05$ vs. Nor. ${ }^{*} p<0.05,{ }^{* *} p<0.01$ vs. Cont (A), ${ }^{*} p<0.05$ vs. Cont. ${ }^{*} p<0.05,{ }^{* *} p<0.01$ vs. Nor (B)

(A)
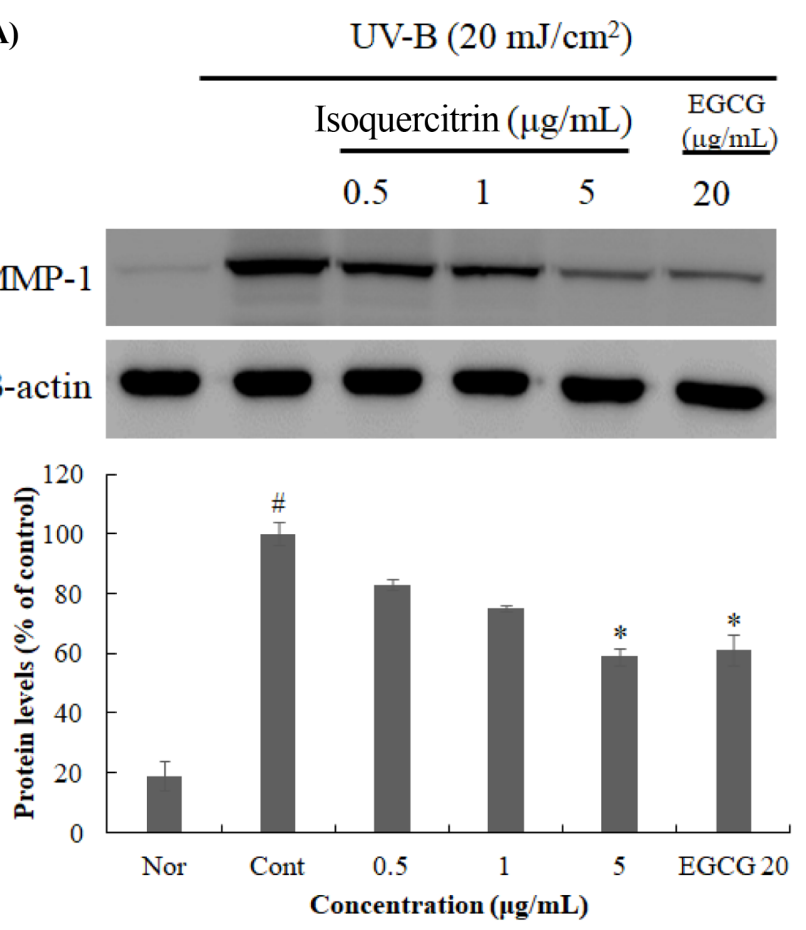

(B)
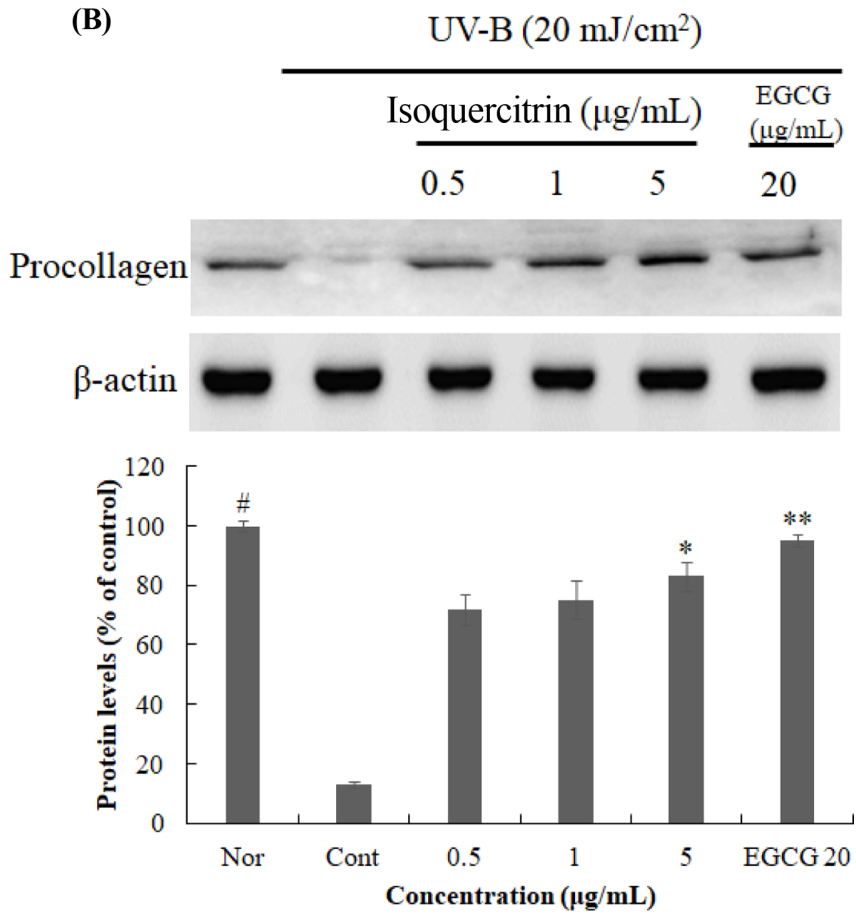

Fig. 6 Recovery effect of IQC on UVB-induced MMP-1 increase (A) and procollagen decrease (B) in CCD-986sk protein extracts. Nor, non-treated; Cont, treated with UV-B $+\mathrm{TNF}-\alpha$. Result are means $\pm \mathrm{SD}$ of triplicate data. ${ }^{*} p<0.05$ vs. Nor. ${ }^{*} p<0.05$ vs. Cont (A), ${ }^{*} p<0.05$ vs. Cont. ${ }^{*} p<0.05$, $* * p<0.01$ vs. Nor (B)

합성율은 동일한 농도에서 $70 \%$ 로 확인되었다[15]. 위 결과로 보아 어리연꽃 정제물인 IQC는 우수한 화장품 소재로서 이용 가치가 있다고 사료된다.

\section{초 록}

본 연구에서는 어리연꽃에서 분리된 isoquercitrin (IQC)를 이용 하여 ROS 활성 억제, procollagen 합성유도, MMP-1의 발현억 제를 측정함으로써 주름개선 기능성 화장품 원료로서의 가능성
을 평가하였다. 그 결과, ROS는 농도의존적으로 억제하는 경향 을 나타내었고 procollagen protein 합성증가율은 대조군과 비교 하여 $70 \%(5 \mu \mathrm{g} / \mathrm{mL})$, MMP-1 protein은 $41 \%(5 \mu \mathrm{g} / \mathrm{mL})$ 의 억 제 활성을 보여주었다. 이것으로 $\mathrm{IQC}$ 의 procollagen 합성유도능 과 ROS 및 MMP-1의 강력한 저해효과를 확인 할 수 있었다. 따라서 어리연꽃에서 분리된 $\mathrm{IQC}$ 는 기능성 화장품 소재로 할 충분한 가치가 있다고 사료된다.

Keywords 섬유아세포 - 어리연꽃 - 엘라스타제 · 주름 억제 · 프로콜라겐 · 항산화 
감사의 글 이 연구는 보건복지부 보건의료연구개발사업( $\mathrm{HN} 15 \mathrm{C} 0103)$ 의 일 환으로 수행하였음.

\section{References}

1. Jenkins G (2002) Molecular mechanisms of skin ageing. Mech Ageing Dev 123: $801-810$

2. Charous SJ, Stricklin GP, Nanney LB, Burkey BB (1997) Expression of matrix metalloproteinases and tissue inhibitor of metalloproteinases in head and neck squa-mous cell carcinoma. Ann Oto Rhino 106: 271-278

3. So SH, Lee SK, Hwang EI, Koo BS, Han GH, Lee MJ, Chung JH, Kim NM (2008) Mecha-nisms of Korean red ginseng and herb extracts (KTNG0345) for anti-wrinkle activity, J Ginseng Res 32(1): 39-47

4. Oh JH, Kim A, Park JM, Kim SH, Chung AS (2006) Ultraviolet Binduced matrix metalloproteinase- 1 and -3 secretion are mediated via PTEN/Akt pathway in human dermal fibroblasts. J Cell Physiol 209(3): 775-785

5. Brincherhoff CE, Rutter JL, Benbow U (2000) Interstitial collagenases as markers of tumor progression. Clin Cancer Res 6: 4823-4830

6. Sang QXA (1998) Complex role of matrix metalloproteinases in angiogenesis. Cell Research 8: 171-177

7. Wang Y, Johnson AR, Ye QZ, Dyer RD (1999) Catalytic activities and substrate specificity of the human membrane type 4 matrix metalloproteinase catalytic domain. J Biol Chem 274: 33043-33049

8. Hong JK (2009) A Study on Skin Aging Caused by Free-Radical and on Efficacy of Antioxidant Vitamins. Asian J Beauty Cos 7(7): 51-62

9. Oh MJ, Min SR, Liu JR, Kim SW (2007) Plant regeneration from floral stem cultures of Nymphoides indica (L.) O. Kuntze. Via somatic embryogenesis. J Plant Biotechnol 34(1): 7-10

10. Lee BY, Nam GH, Lee JY, Park CH, Lim CE, Kim MH, Lee SJ, Roh TK, Lim JA, Han JE, Kim JH (2011) National List of Species of Korea (Vascular Plants). National Institute of Biological Resources. Incheon

11. Amin A (2016) Phytochemical and Pharmacological investigations on Nymphoides indica Leaf extracts. Phytother Res 30: 1624-1633

12. Cannell RJ, Kellam SJ, Owsianka AM, Walker JM (1998) Results of a large scale screen of microalgae for the production of protease inhibitors. Planta Med 54: 10-14

13. Shim JS, Kim SD, Kim TS, Kim KN (2005) Biological activities of flavonoid glycosides isolated from Angelica keiskei. Korean J Food Sci Technol 30(1): 78-83

14. Kim MJ, Kim JY, Jung TK, Choi SW, Yoon KS (2006) Skin anti-aging effect of Forsythia viridissima L. extract. Korean J Biotechnol Bioeng 21(6): 444-450

15. Choi EY, Kim EH, Lee JB, Do EJ, Kim SJ, Kim SH, Park JY, Lee JT (2016) Mechanisms for anti-wrinkle activities from fractions of Black Chokeberries. J Life Sci 26(1): 34-41 